\title{
Halorubrum luteum sp. nov., isolated from Lake Chagannor, Inner Mongolia, China
}

Correspondence

Yanfen Xue

xueyf@im.ac.cn
Lingfei Hu, ${ }^{1,2}$ Hailian Pan, ${ }^{1}$ Yanfen Xue, ${ }^{1}$ A. Ventosa, ${ }^{3}$ D. A. Cowan, ${ }^{4}$ B. E. Jones, ${ }^{5}$ W. D. Grant ${ }^{6}$ and Yanhe $\mathrm{Ma}^{1}$

\footnotetext{
${ }^{1}$ State Key Laboratory of Microbial Resources, Institute of Microbiology, Chinese Academy of Sciences, Beijing 100101, PR China

${ }^{2}$ Graduate School of the Chinese Academy of Sciences, Beijing 100049, PR China

${ }^{3}$ Department of Microbiology and Parasitology, Faculty of Pharmacy, University of Sevilla, 41012 Sevilla, Spain

${ }^{4}$ Department of Biotechnology, University of the Western Cape, Bellville 7535, Cape Town, South Africa

${ }^{5}$ Genencor International BV, Archimedesweg 30, 2333 CN Leiden, The Netherlands

${ }^{6}$ Department of Infection, Immunity and Inflammation, University of Leicester, Leicester LE1 9HN, UK
}

A novel halophilic archaeon, strain CGSA $15^{\top}$, was isolated from water of Lake Chagannor in China. The strain grew optimally at $33-37{ }^{\circ} \mathrm{C}, \mathrm{pH} 9.5-10.0$ and 4.0-4.3 M NaCl. The major polar lipids were phosphatidylglycerol and phosphatidylglycerol phosphate methyl ester. The genomic DNA G + C content of strain CGSA $15^{\top}$ was 60.2 mol\%. Phylogenetic analysis based on $16 \mathrm{~S}$ rRNA gene sequences revealed that strain $\mathrm{CGSA} 15^{\top}$ was a member of the genus Halorubrum and was related most closely to Halorubrum alkaliphilum AS $1.3528^{\top}$ (96.1\% similarity) and Halorubrum tibetense AS $1.3239^{\top}$ (96.9\%). Levels of DNA-DNA relatedness between strain CGSA $15^{\top}$ and Hrr. alkaliphilum AS $1.3528^{\top}$ and Hrr. tibetense AS $1.3239^{\top}$ were 36.7 and $28.9 \%$, respectively. According to the phenotypic and genotypic data presented, strain CGSA $15^{\top}$ is considered to represent a novel species of the genus Halorubrum, for which the name Halorubrum luteum sp. nov. is proposed. The type strain is CGSA15 ${ }^{\top}\left(=\mathrm{CGMCC}_{1.6783^{\top}}\right.$ $=$ CECT $7303^{\top}$ ).
The genus Halorubrum was first proposed by McGenity \& Grant (1995) to accommodate several species previously included in the genus Halobacterium: Halorubrum saccharovorum (Tomlinson \& Hochstein, 1976), Halorubrum sodomense (Oren, 1983), Halorubrum trapanicum (Petter, 1931) and Halorubrum lacusprofundi (Franzmann et al., 1988). At the time of writing, Halorubrum is the largest genus within the family Halobacteriaceae, with 19 recognized species, three of which are alkaliphilic and 16 neutrophilic (Cui et al., 2007; Xu et al., 2007; Castillo et al., 2007). Of the three alkaliphilic species, Halorubrum vacuolatum was isolated from Lake Magadi, Kenya (Mwatha \& Grant, 1993), Halorubrum tibetense from Lake Zabuye, Tibet, China (Fan et al., 2004), and

The GenBank/EMBL/DDBJ accession number for the $16 \mathrm{~S}$ rRNA gene sequence of strain CGSA $15^{\top}$ is DQ987877.

Micrographs of cells of strain CGSA $15^{\top}$ and figure showing the polar lipid pattern of strain CGSA $15^{\top}$ are available as supplementary material with the online version of this paper.
Halorubrum alkaliphilum from a soda lake of Xinjiang, China (Feng et al., 2005). Here, we report on the taxonomic characterization of a novel alkaliphilic species of the genus Halorubrum, which was isolated from a soda lake of Inner Mongolia, China.

Strain CGSA $15^{\mathrm{T}}$ was isolated from a water sample of Lake Chagannor $\left(43^{\circ} 16^{\prime} 13^{\prime \prime} \mathrm{N} 112^{\circ} 55^{\prime} 63^{\prime \prime} \mathrm{E}\right)$ located in Inner Mongolia Autonomous Region, China. At the time of sampling (September 2003), the water of the lake had a temperature of $17{ }^{\circ} \mathrm{C}$, a $\mathrm{pH}$ of 10.5 and a salinity of $18 \%$. The strain was isolated by a direct dilution plate method and was purified by repeated streaking. The medium used for isolation and cultivation contained (per litre distilled water): $7.5 \mathrm{~g}$ Casamino acids (Difco), $10.0 \mathrm{~g}$ yeast extract (Difco), $3.0 \mathrm{~g}$ trisodium citrate, $2.0 \mathrm{~g} \mathrm{MgSO}_{4} \cdot 7 \mathrm{H}_{2} \mathrm{O}$, $10.0 \mathrm{~g} \mathrm{KCl}$, trace $\mathrm{Fe}^{2+}$ and $\mathrm{Mn}^{2+}, 200 \mathrm{~g} \mathrm{NaCl}$ and $10.0 \mathrm{~g}$ $\mathrm{Na}_{2} \mathrm{CO}_{3}$. When grown on agar medium with $4.0 \mathrm{M} \mathrm{NaCl}$ at $37{ }^{\circ} \mathrm{C}$ for 7 days, strain CGSA $15^{\mathrm{T}}$ formed orange, convex, entire and circular colonies. Cells of strain CGSA $15^{\mathrm{T}}$ were motile and pleomorphic in liquid cultures, 
as determined by phase-contrast microscopy without fixation and by Gram staining with acetic acid fixation (Dussault, 1955). Peritrichous tufts of flagella were observed by negative staining (Kodaka et al., 1982) and transmission electron microscopy of exponentially growing liquid cultures. Micrographs of cells of strain $\mathrm{CGSA}^{\mathrm{T}} 5^{\mathrm{T}}$ are available as Supplementary Fig. S1 in IJSEM Online.

Phenotypic tests were carried out in accordance with the proposed minimal standards for the description of new taxa in the order Halobacteriales (Oren et al., 1997) and included anaerobic growth in the presence of nitrate or arginine, catalase and oxidase activities, hydrolysis of starch, Tween 80, gelatin and casein, nitrate and nitrite reduction, $\mathrm{H}_{2} \mathrm{~S}$ and indole formation and the utilization of sugars, alcohols, amino acids and organic acids. Antibiotic sensitivity tests were performed by spreading bacterial suspensions on culture plates and applying discs impregnated with the antibiotics to be tested. The type strains of Hrr. tibetense, Hrr. alkaliphilum and Hrr. vacuolatum were used as reference strains. Detailed results of the physiological and biochemical tests as well as the antibiotic susceptibility tests are given in the species description below. Differential characteristics between strain CGSA $15^{\mathrm{T}}$ and other alkaliphilic members of the genus Halorubrum are shown in Table 1.
Polar lipids were extracted and analysed by the methods of Kamekura \& Kates (1988) by using two-dimensional TLC (Merck DC silica gel 60 $\mathrm{F}_{254}$ plates, layer thickness $0.2 \mathrm{~mm}$; art. 5554). The first direction was developed in chloroform/ methanol/water ( $65: 25: 4$, by volume) and the second in chloroform/methanol/acetic acid/water $(80: 12: 15: 4$, by volume). Phospholipids were detected as blue spots by spraying with Zinzadze reagent. All other lipids were visualized by spraying with sulfuric acid/ethanol $(1: 1, \mathrm{v} / \mathrm{v})$, followed by heating at $150{ }^{\circ} \mathrm{C}$. The major polar lipids of strain CGSA $15^{\mathrm{T}}$ were phosphatidylglycerol and methylated phosphatidylglycerol phosphate (Supplementary Fig. S2). Glycolipid and phosphatidylglycerol sulfate were absent. This characteristically simple polar-lipid pattern is shared with other alkaliphilic members of the genus Halorubrum (Mwatha \& Grant, 1993; Fan et al., 2004; Feng et al., 2005).

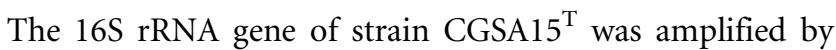
PCR by using the modified primers described by Yang et al. (2007) and was directly sequenced on an ABI 373A DNA sequencer. Phylogenetic trees based on $16 \mathrm{~S}$ rRNA gene sequences were constructed by using the neighbour-joining, minimum-evolution and maximum-parsimony methods in the MEGA3 program package (Kumar et al., 2004). The stability of relationships was assessed by bootstrap analysis (1000 replications). The tree based on the neighbour-joining

Table 1. Differential characteristics between strain CGSA $15^{\top}$ and other alkaliphilic Halorubrum species

Data are from Mwatha \& Grant (1993), Fan et al. (2004), Feng et al. (2005) and the present study. +, Positive; -, negative; w +, weakly positive; $\mathrm{ND}$, no data available.

\begin{tabular}{|c|c|c|c|c|}
\hline Characteristic & Strain CGSA15 ${ }^{\mathrm{T}}$ & $\begin{array}{l}\text { Hrr. alkaliphilum } \\
\quad \text { AS } 1.3528^{\mathrm{T}}\end{array}$ & $\begin{array}{c}\text { Hrr. tibetense } \\
\text { AS } 1.3239^{\mathrm{T}}\end{array}$ & $\begin{array}{l}\text { Hrr. vacuolatum } \\
{\text { JCM } 9060^{\mathrm{T}}}\end{array}$ \\
\hline Cell shape & Pleomorphic rods & Short rods & Irregular rods & Pleomorphic short rods \\
\hline Motility & + & + & - & - \\
\hline Colony colour & Orange & Red & Red & Bright pink \\
\hline \multicolumn{5}{|c|}{$\mathrm{NaCl}$ concentration for growth (M) } \\
\hline Range & $2.5-5.2$ & $1.8-5.2$ & $1.7-5.2$ & $2.5-5.2$ \\
\hline Optimum & $4.0-4.3$ & $3.9-4.3$ & $3.0-3.4$ & 3.5 \\
\hline \multicolumn{5}{|l|}{ Growth temperature $\left({ }^{\circ} \mathrm{C}\right)$} \\
\hline Optimum & $33-37$ & 38 & $37-40$ & $35-40$ \\
\hline Range & $17-41$ & $20-44$ & $22-45$ & $20-50$ \\
\hline $\mathrm{pH}$ range for growth & $7.5-10.5$ & $8.0-10.5$ & $8.0-10.5$ & $8.5-10.5$ \\
\hline $\mathrm{H}_{2} \mathrm{~S}$ formation & + & + & - & $\mathrm{ND}$ \\
\hline Indole formation & + & + & - & ND \\
\hline Tween 80 hydrolysis & - & - & + & ND \\
\hline \multicolumn{5}{|l|}{ Utilization of: } \\
\hline Fructose & - & + & ND & - \\
\hline Galactose & - & - & - & + \\
\hline Sucrose & - & - & + & + \\
\hline Maltose & + & + & + & - \\
\hline Lactose & $\mathrm{w}+$ & - & + & $\mathrm{ND}$ \\
\hline Mannitol & $\mathrm{w}+$ & - & + & - \\
\hline Succinate & + & - & + & + \\
\hline Acetate & - & - & + & + \\
\hline DNA G $+C$ content $(\mathrm{mol} \%)$ & 60.2 & 62.1 & 63.3 & 62.7 \\
\hline
\end{tabular}




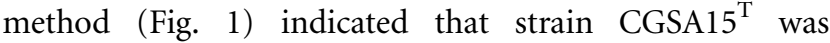
phylogenetically related to the genus Halorubrum, and was related most closely to Hrr. alkaliphilum AS $1.3528^{\mathrm{T}}$ (96.1\% $16 \mathrm{~S}$ rRNA gene sequence similarity) and Hrr. tibetense AS $1.3239^{\mathrm{T}}(96.9 \%)$. Similar tree topologies were obtained with the minimum-evolution and maximum-parsimony algorithms (data not shown).

Genomic DNA was extracted by using the method of $\mathrm{Ng}$ et al. (1995). The DNA G+C content of strain CGSA $15^{\mathrm{T}}$ was $60.2 \mathrm{~mol} \%$, as determined by thermal denaturation (Marmur \& Doty, 1962). DNA-DNA hybridizations were performed with the thermal denaturation and renaturation method (De Ley et al., 1970; Huß et al., 1983) by using a Beckman DU 800 spectrophotometer. Levels of DNA-DNA relatedness between strain CGSA $15^{\mathrm{T}}$ and Hrr. alkaliphilum AS $1.3528^{\mathrm{T}}$ and Hrr. tibetense AS $1.3239^{\mathrm{T}}$ (its closest relatives as judged from $16 \mathrm{~S}$ rRNA gene sequence analyses) were 36.7 and $28.9 \%$, respectively. Taking these results in combination with the levels of $16 \mathrm{~S}$ rRNA gene sequence similarity, strain CGSA $15^{\mathrm{T}}$ is thus not genotypically related to any recognized species of the genus Halorubrum (Goebel \& Stackebrandt, 1994; Oren et al., 1997).

On the basis of the data described above, strain CGSA $15^{\mathrm{T}}$ should be placed in the genus Halorubrum as representing a novel species. Strain CGSA15 ${ }^{\mathrm{T}}$ can be distinguished easily from other alkaliphilic members of the genus Halorubrum by its production of orange pigments. The name proposed for this novel organism is Halorubrum luteum sp. nov.

\section{Description of Halorubrum luteum sp. nov.}

Halorubrum luteum (lu.te'um. L. neut. adj. luteum orange coloured).

Cells are Gram-negative, pleomorphic $(0.5-0.9 \times 0.6-$ $1.5 \mu \mathrm{m})$ and motile. Colonies growing on agar medium containing $4.0 \mathrm{M} \mathrm{NaCl}$ are small (1-2 $\mathrm{mm}$ in diameter), entire, smooth, round and orange. Chemo-organotrophic and aerobic. Growth occurs at $\mathrm{NaCl}$ concentrations of 2.5$5.2 \mathrm{M}$, at $\mathrm{pH} 7.5-10.5$ and at $17-41{ }^{\circ} \mathrm{C}$. Optimal $\mathrm{NaCl}$ concentration, $\mathrm{pH}$ and temperature for growth are 4.0$4.3 \mathrm{M}$, pH 9.5-10.0 and $33-37{ }^{\circ} \mathrm{C}$. Magnesium is not required for growth. Cells lyse in distilled water. Catalaseand oxidase-positive. Anaerobic growth with nitrate, arginine or DMSO does not occur. Nitrate reduction to nitrite is observed. $\mathrm{H}_{2} \mathrm{~S}$ is produced from $\mathrm{Na}_{2} \mathrm{~S}_{2} \mathrm{O}_{3}$. Indole formation is positive. Tween 80 , casein and starch are not hydrolysed. Gelatin is not liquefied. Glucose, mannose, maltose, lactose, mannitol and D-sorbitol are utilized but acid production is not clearly observed. Growth occurs on succinate, L-aspartic acid, pyruvate, glycerol, DL-lactate, Lmalate, fumarate, citrate, glycine, L-alanine, L-glutamate and L-ornithine. The following compounds are not used as sole carbon and energy sources: fructose, xylose, sorbose, galactose, D-ribose, sucrose, L-lysine, acetate, starch and Larginine. Sensitive to erythromycin $(15 \mu \mathrm{g})$ and novobiocin $(30 \mu \mathrm{g})$. Resistant to neomycin $(30 \mu \mathrm{g})$, rifampicin $(5 \mu \mathrm{g})$, chloramphenicol $(30 \mu \mathrm{g})$, bacitracin (0.04 IU), ampicillin $(10 \mu \mathrm{g})$, penicillin $\mathrm{G}(10 \mathrm{IU})$, norfloxacin $(10 \mu \mathrm{g})$, ciprofloxacin $(5 \mu \mathrm{g})$, streptomycin $(10 \mu \mathrm{g})$, kanamycin $(30 \mu \mathrm{g})$, tetracycline $(30 \mu \mathrm{g})$ and vancomycin $(30 \mu \mathrm{g})$. Cells contain phosphatidylglycerol and phosphatidylglycerol phosphate methyl ester, but lack phosphatidylglycerol sulfate and glycolipids. The $\mathrm{G}+\mathrm{C}$ content of the DNA of the type strain is $60.2 \mathrm{~mol} \%\left(T_{\mathrm{m}}\right)$.

The type strain, CGSA15 ${ }^{\mathrm{T}}\left(=\mathrm{CGMCC} 1.6783^{\mathrm{T}}=\mathrm{CECT}\right.$ $7303^{\mathrm{T}}$ ), was isolated from Lake Chagannor in Inner Mongolia, China.

\section{Acknowledgements}

This work was supported by grants from the Chinese Academy of Sciences (Knowledge Innovation Program, KSCX2-YW-G-011), the Ministry of Science and Technology of China (863 programs,

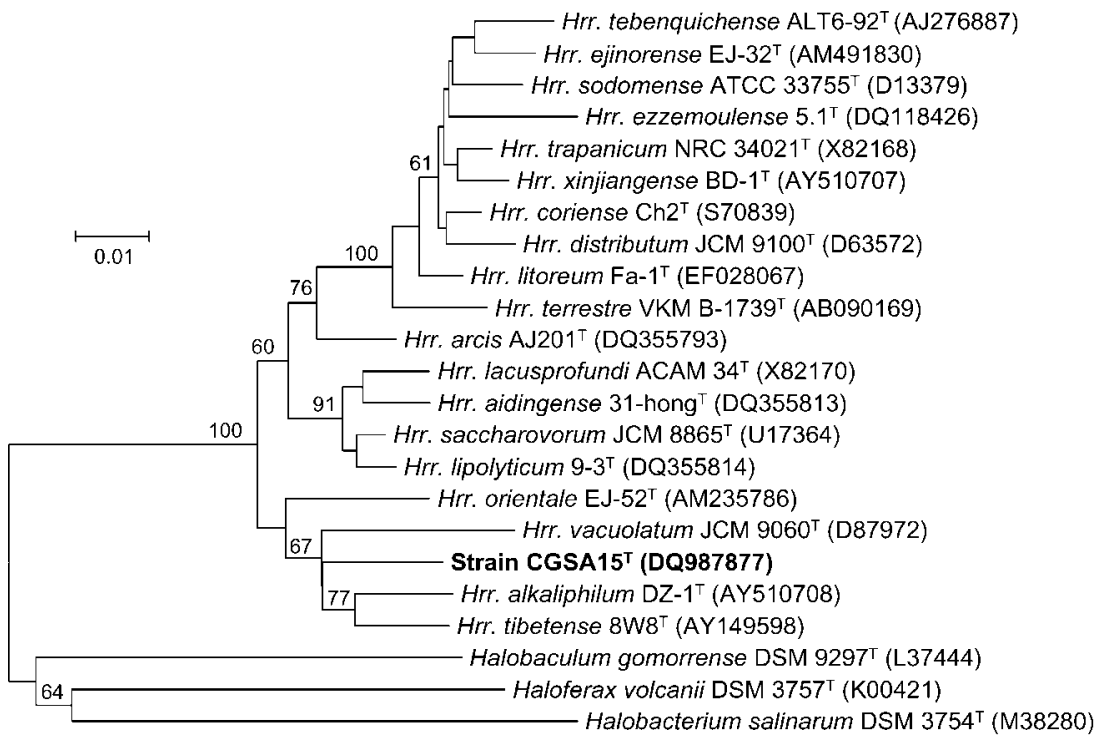

Fig. 1. Neighbour-joining phylogenetic tree based on $16 \mathrm{~S}$ rRNA gene sequences showing the relationship of strain $\mathrm{CGSA} 15^{\top}$ amongst recognized members of the genus Halorubrum. Bootstrap values (\%) are based on 1000 replicates and are shown for branches with $\geqslant 60 \%$ bootstrap support. Bar, 0.01 expected changes per site. 
2006AA020201 and 2007AA021306; 973 program, 2004CB719605 and 2007CB707801) and the European Commission (Project 'Multigenome Access Technology for Industrial Catalysts', QLK3CT-2002-01972).

\section{References}

Castillo, A. M., Gutiérrez, M. C., Kamekura, M., Xue, Y., Ma, Y., Cowan, D. A., Jones, B. E., Grant, W. D. \& Ventosa, A. (2007). Halorubrum ejinorense sp. nov., isolated from Lake Ejinor, Inner Mongolia, China. Int J Syst Evol Microbiol 57, 2538-2542.

Cui, H. L., Lin, Z. Y., Dong, Y., Zhou, P. J. \& Liu, S. J. (2007). Halorubrum litoreum sp. nov., an extremely halophilic archaeon from a solar saltern. Int J Syst Evol Microbiol 57, 2204-2206.

De Ley, J., Cattoir, H. \& Reynaerts, A. (1970). The quantitative measurement of DNA hybridization from renaturation rates. Eur $J$ Biochem 12, 133-142.

Dussault, H. P. (1955). An improved technique for staining red halophilic bacteria. J Bacteriol 70, 484-485.

Fan, H., Xue, Y., Ma, Y., Ventosa, A. \& Grant, W. D. (2004). Halorubrum tibetense sp. nov., a novel haloalkaliphilic archaeon from Lake Zabuye in Tibet, China. Int J Syst Evol Microbiol 54, 1213-1216.

Feng, J., Zhou, P., Zhou, Y. G., Liu, S. J. \& Warren-Rhodes, K. (2005). Halorubrum alkaliphilum sp. nov., a novel haloalkaliphile isolated from a soda lake in Xinjiang, China. Int J Syst Evol Microbiol 55, 149-152.

Franzmann, P. D., Stackebrandt, E., Sanderson, K., Volkman, J. K., Cameron, D. E., Stevenson, P. L., McMeekin, T. A. \& Burton, H. R. (1988). Halobacterium lacusprofundi sp. nov., a halophilic bacterium isolated from Deep Lake, Antarctica. Syst Appl Microbiol 11, 20-27.

Goebel, B. M. \& Stackebrandt, E. (1994). Cultural and phylogenetic analysis of mixed microbial populations found in natural and commercial bioleaching environments. Appl Environ Microbiol 60, 1614-1621.

Huß, V. A. R., Festl, H. \& Schleifer, K. H. (1983). Studies on the spectrophotometric determination of DNA hybridization from renaturation rates. Syst Appl Microbiol 4, 184-192.

Kamekura, M. \& Kates, M. (1988). Lipids of halophilic archaebacteria. In Halophilic Bacteria II, pp. 25-54. Edited by F. Rodriguez-Valera. Boca Raton, FL: CRC Press.

Kodaka, H., Armfield, A. Y., Lombard, G. L. \& Dowell, V. R., Jr (1982). Practical procedure for demonstrating bacterial flagella. J Clin Microbiol 16, 948-952.
Kumar, S., Tamura, K. \& Nei, M. (2004). MEGA3: integrated software for molecular evolutionary genetics analysis and sequence alignment. Brief Bioinform 5, 150-163.

Marmur, J. \& Doty, P. (1962). Determination of the base composition of deoxyribonucleic acid from its thermal denaturation temperature. $J$ Mol Biol 5, 109-118.

McGenity, T. J. \& Grant, W. D. (1995). Transfer of Halobacterium saccharovorum, Halobacterium sodomense, Halobacterium trapanicum NRC 34021 and Halobacterium lacusprofundi to the genus Halorubrum gen. nov., as Halorubrum saccharovorum comb. nov., Halorubrum sodomense comb. nov., Halorubrum trapanicum comb. nov., and Halorubrum lacusprofundi comb. nov. Syst Appl Microbiol 18, 237-243.

Mwatha, W. E. \& Grant, W. D. (1993). Natronobacterium vacuolatum sp. nov., a haloalkaliphilic archaeon isolated from Lake Magadi, Kenya. Int J Syst Bacteriol 43, 401-404.

Ng, W. L., Yang, C. F., Halladay, J. T., Arora, A. \& DasSarma, S. (1995). Protocol 25. Isolation of genomic and plasmid DNAs from Halobacterium halobium. In Archaea: a Laboratory Manual: Halophiles, pp. 179-180. Edited by S. DasSarma \& E. M. Fleischmann. Cold Spring Harbor, NY: Cold Spring Harbor Laboratory Press.

Oren, A. (1983). Halobacterium sodomense sp. nov., a Dead Sea halobacterium with an extremely high magnesium requirement. Int $J$ Syst Bacteriol 33, 381-386.

Oren, A., Ventosa, A. \& Grant, W. D. (1997). Proposed minimal standards for description of new taxa in the order Halobacteriales. Int J Syst Bacteriol 47, 233-238.

Petter, H. F. M. (1931). On the bacteria of salted fish. Proc K Ned Akad Wet Amsterdam 34, 1417-1423 (in Dutch).

Tomlinson, G. A. \& Hochstein, L. I. (1976). Halobacterium saccharovorum sp. nov., a carbohydrate-metabolizing, extremely halophilic bacterium. Can J Microbiol 22, 587-591.

Xu, X. W., Wu, Y. H., Zhang, H. B. \& Wu, M. (2007). Halorubrum arcis sp. nov., an extremely halophilic archaeon isolated from a saline lake on the Qinghai-Tibet Plateau, China. Int J Syst Evol Microbiol 57, 1069-1072.

Yang, Y., Cui, H. L., Zhou, P. J. \& Liu, S. J. (2007). Haloarcula amylolytica sp. nov., an extremely halophilic archaeon isolated from Aibi salt lake in Xin-Jiang, China. Int J Syst Evol Microbiol 57, 103-106. 